\title{
Gastric Large Cell Neuroendocrine
} Carcinoma

National Cancer Institute

\section{Source}

National Cancer Institute. Gastric Large Cell Neuroendocrine Carcinoma. NCI Thesaurus.

Code C95885.

An aggressive, high-grade and poorly differentiated carcinoma with neuroendocrine

differentiation that arises from the stomach. It is characterized by the presence of malignant large cells. 